\title{
Editorial
}

\section{AUMENTO SUBSTANCIAL DE MATRÍCULAS DE ENFERMEIROS E TECNICOS DE ENFERMAGEM}

Pela primeira vez, nestes cinqüenta e um anos de existência de escolas superiores de enfermagem no País, as matrículas na primeira série do Curso de Graduação ultrapassaram os dois milhares. E bem verdade que esse número é pequeno e nem de longe se aproxima do que o País necessita, segundo as metas aprovadas pelo Governo.

Apesar da ressalva assinalada, é grande o regozijo desta Associação com os aumentos de matrícula em todos os cursos, - de enfermeiros, técnicos de enfermagem e de auxiliares de enfermagem.

A ABEn está empreendendo esforços no sentido de o Ministério da Educação e Cultura constituir um órgão de assessoria em assuntos de educação de enfermagem - seria uma Comissão de Ensino de Enfermagem, a exemplo da Comissão de Ensino de Agronomia, de Medicina e outras já em funcionamento. Tais comissões estão previstas nas normas atuais para darem colaboração ao Departamento de Assuntos Universitários - D.A.U. - e ao Conselho Federal de Educação.

Segundo uma pequena pesquisa em andamento, com dados sujeitos a retificação, houve 1867 e 2083 alunos matriculados na 1.a série respectivamente em 1973 e 1974 nos 79 cursos de graduação de enfermagem, resultando em $12 \%$ de aumento, em um ano.
Segundo os achados da Comissão de Documentação e Estudos desta Associação - com totais sujeitos a acréscimo, uma vez que quatro escolas adicionalmente deverão remeter seus dados - o total de matrícula na $1 .^{\mathrm{a}}$ série foi de 387 em 1973 e 970 em 1974 em 26 escolas, resultando no aumento, em um ano, de $60 \%$.

Também quanto aos técnicos o número está ainda muito abaixo do necessário.

Urge que as enfermeiras tomem providências junto às autoridade competentes para que se obtenha a criação de quadros e tabelas de empregos regidos pela CLT para enfermeiros, técnicos de enfermagem e auxiliares de enfermagem. Quanto aos técnicos de enfermagem, é necessário e urgente criarem-se tais empregos regidos pela CLT. Seus cursos são regidos pela Lei 5.692 de 1971 (e legislação anterior, art. 47 da LDB, Parágrafo único) e sem dúvida podem ser criados seus empregos, nas organizações públicas e privadas. $O$ nível poderá ser próximo e abaixo do nível dos enfermeiros.

Esta Associação está desenvolvendo ações no sentido de criar condições de trabalho, de progresso profissional, bemestar e harmonia no grupo das ocupações de enfermagem. (HGD) 